\title{
Leading Communities: Community-led Development in England's Small Towns: the Market Towns Initiative
}

\author{
Gordon Morris \\ University of Exeter \\ Centre for Rural Policy Research
}

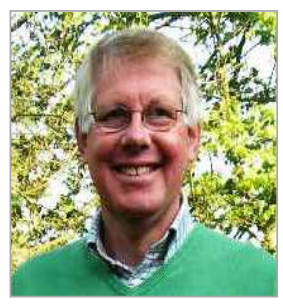

\begin{abstract}
The Market Towns Initiative (MTI), a UK community-led development programme, operated throughout rural England from 2000 until 2005/6. It was designed to help local people, with professional support, identify - and then capitalize on - the economic, environmental and social strengths and weaknesses of small country towns.
\end{abstract}

This paper explains the origins and ways of working of the MTI. Examples of the topics explored and participants' views are given, and conclusions drawn. The opportunity is also taken to explain how interest in the roles of England's small country towns grew in the years following the Second World War, and how this led to the development of the MTI.

Evidence suggests that the programme worked well. It demonstrated that local people have the enthusiasm, skills and knowledge to take a lead in the development of the places in which they live; something which, until local government reforms changed roles and structures, was largely taken for granted.

\section{Introduction}

The Market Towns Initiative (MTI), a regionally organized, nationally coordinated, but locally led partnership-based development programme, operated throughout rural England between 2000 and 2005/6. It was available to any country town with a population between 2,000 and $20,000^{24}$. The approach was developed by the Countryside Agency, a government “arms-length” organization (quango ${ }^{25}$ ), and was supported by public and voluntary sector organizations. Its purpose was to help, “local people to appraise strengths, weaknesses, future demands and opportunities" (AMT 2005, p. iii), in short, to help influence and lead local development policy and practice in their town.

\footnotetext{
${ }^{24}$ Unlike earlier rural development programmes during the 1990s (Moseley and Clark 1998), and the EU's LEADER programmes (http://tinyurl.com/cnge88t), the MTI was available throughout rural England, as was its fellow programme for smaller settlements, Vital Villages (http://tinyurl.com/cagnfw2).

${ }^{25}$ Quango: quasi autonomous non-governmental organization, an organization paid to do specified work using public funds, but having relative freedom from direct political control. The Countryside Agency was formed from the merger of the Rural Development and Countryside Commissions. Its remit covered both socio-economic and environmental aspects of rural life (CA 1999a p3).
} 
The present UK government, like its New Labour predecessors, has emphasized its desire to return power to local people. It enacted the Localism Bill in 2011 (UK Parliament 2011), and much has been made of the Prime Minister's personal commitment to the "Big Society" (Cameron 2011). However, although certain powers have been, or will be, returned to local authorities (e.g. allowing councils more discretion over certain aspects of a local business tax, and responsibility for public health), and local people have been given the right to call for referenda on some local matters, there remains an impression that government is, “... passing the buck without the bucks ...”, at least in relation to public health (Hetherington 2012).

Nevertheless, there is political interest in the debate about how to devolve power and increase local participation in democracy, and, more widely, through greater involvement in those well-known abstractions - neighbourhoods and communities (Conservative Party 2009, DCLG 2011, Miliband 2006). There is also wider interest, for example from within the Co-operative movement, which is trying to, “... measure and ... improve community living” (Wilson 2012) an aim which lay at the heart of the MTI.

This paper, which has two main purposes, draws both on the writer's professional involvement in the development and implementation of the programme and on his evaluation of its effectiveness (Morris 2010).

The first purpose is to explain how interest in the functions of England's country towns grew from the late 1940s onwards. The post-war period saw counter-urbanization gather pace (CRC 2007, p.14), the age profile of the rural population tilt towards the over-65s (p.14), and small town living become increasingly popular, with approximately half of the rural population estimated to be living in country towns by 2005 (CRC 2008, p.12). These developments, coupled with wider societal changes (e.g. growth in car ownership, increased standards of living that enabled people to travel more freely for work, leisure and services, changes in rural employment, and in local government structures) by the 1990s resulted in increased interest in, and concern for, small towns amongst local people and some politicians and policymakers. This concern was eventually recognized by central government in two white papers, in the second of which announced the MTI (DoE/MAFF 1995, p.57, DETR 2000, p.75).

The second purpose is to explain the MTI's aims and approach, and to describe some of the work and achievements of the 247 participating town partnerships. Information is presented from the writer's research, which set out to assess the MTI's effectiveness in terms of its strengths, weaknesses and achievements $^{26}$. Findings, drawn from a combination of interviews (with people involved with rural policy, the programme, and work in the case study town) and a postal survey of a selection of

\footnotetext{
${ }^{26}$ The research also assessed the extent to which the programme addressed rural poverty. This aspect of the work is not discussed in this paper, but is noted for the purposes of completeness.
} 
participating partnerships, suggest that the programme worked well. However, the data also revealed the well-known imperfections of partnership working (Geddes 2000, pp.794-795, Woods 2005, p.169) - as well as some of the strengths (Bevir and Rhodes 2003, pp.71-72, The Leeds Initiative 2009, p.18). The findings also suggest that the programme could usefully inform future work, and that local people have much to offer in terms of local development and leadership. Today, approximately six years since the programme formally ended, and despite continuing government centralization, there is now more interest in these diverse places than, as the next section illustrates, was once the case.

\section{Interest in small towns grew, as their roles and responsibilities changed}

Between the thirteenth and nineteenth centuries, small towns were the main centres of local influence and power, with power moving from monarch to sheriffs, and to mercantilist mayors at the head of powerful trade guilds (Chamberlin 1984, pp.144-146). As the franchise was gradually extended so power moved towards more democratic - and remote - forms of local government, with the creation of county councils in 1888, and rural and urban district, and town, councils in 1894 (Bracey 1959, p,67). Central government, the architect of these changes, increased its influence, with legislation and budgets increasingly centrally controlled, although local councils, many of which were centred on small country towns, retained ownership and management of, e.g. local electricity generation and supply, until the late 1940s (Greene 2007). As local government powers reduced, administrative functions increased, with the danger that elected councils, irrespective of political party allegiance, became little more than administrative agents of central government (Griffith 1985, pp. xi-xii).

Today, the term, market town, is still accurate for places with mediaeval market charters, and for those which serve market functions. However, although many towns owe their origins to the presence of traders' markets, their governing charters, and their historical role as trading centres for surrounding dependent settlements (Chalkin 1989, pp.37-38). Not all towns have, or have ever had, markets, and some of those that do are now large regional centres.

The idea and image of a market town is powerful, in England at least, but it is unhelpful where policy is concerned (STfT 2012, p.6). England's settlement hierarchy is complicated, both terminologically, and in reality. Settlements range in size from isolated farmsteads and dwellings, through hamlets (small villages, usually without their own church), villages (usually with their own church), small (country) and large (regional) towns to bigger, often densely populated, metropolitan areas. Although the hierarchy works well at the intuitive level, it is more problematical when considered in detail. For example, some villages have populations larger than some towns, and some cities, classed as such because of the presence of a cathedral irrespective of population, are smaller than some small towns.

Where more rigorous analysis is concerned, e.g. about definitions and roles, small towns have long been the subject of debate (HMSO 1942, ERM 2001, Shepherd 2009). Today about 1,600 towns with 
populations between 1,500 and 40,000 are classified as small towns (Shepherd 2009, p.2). However, to complicate matters further, within this range lays the Local Authority Rural-Urban Classification which defines Large Market Towns as those with populations of 10,000-30,000 (Defra 2102, p.6).

The Rural Development Commission (Rogers 1999), the Countryside Agency's predecessor, used a population band of 2,000-10,000 during the 1990s. Although informed by experience, the choice was essentially pragmatic, in that the RDC, limited by remit, staff numbers, and budgets for grants etc., had to restrict the number of towns eligible for help to a manageable number. However, as defining a country town by population alone has proved to be something of a fool's errand, with service functions considered more important, the eventual MTI band (2,000-20,000) was more guide than command (CA 2000, p.1). ${ }^{27}$

Irrespective of definition, small towns are important, particularly given their roles as service centres, their geographical distribution, number, and diversity. Eventually therefore, interest in them grew, gathering pace during the 1980s and 1990s, and peaking in the years during which the MTI was operational. From the middle 2000s, however, when the programme ceased to operate, government priorities changed following foot and mouth disease outbreaks, and changes in policy direction in the responsible department (Environment, Food and Rural Affairs) towards more pressing topics such as climate change.

The arrival of the present Conservative-Liberal Democrat coalition government in 2010 has not brought about a renewed interest in small towns. Indeed, their recent "rural statement” (Defra 2012), makes scant reference and no specific commitments to them.

For the time being, therefore, national political interest in small towns has stalled. This is in marked contrast to the post-war period. Investigations into rural services, transport, and changes in the composition of populations were stimulated by interest in the counter-urbanization and deindustrialization taking place in rural England (Woods 2005, pp.72-90). These studies were mainly ad hoc, and were done by academics for, rather than by, local people (Bracey 1952, 1954, 1962, 1963, Green 1949, 1952, Pahl 1965, Stacey 1960).

Academic interest continued into and beyond the 1970s (Pahl 1970, Mills 1980, Courtney et al 1998, Morris 2003, 2010, Wheway 2012). From the early 1990s, organizations with rural interests researched and monitored aspects of rural life. Examples include "lifestyles" (Cloke et al 1994), rural, as opposed to urban, society (Diocese of Hereford 1987), incomes in relation to housing affordability (Bramley and Smart 1995) - still a pressing concern (Minton 2012 Ch6) - and specific work relating

\footnotetext{
${ }^{27}$ It is perhaps worth noting that, according to research conducted by the RDC (1996), there were only 210 retail markets, and 59 livestock markets in England within the population range selected for the study (3,000-15,000).
} 
to poverty (Nobel and Wright 2000, Morris 2010). Between 1999 and the late 2000s, the condition of rural England from a variety of perspectives, economic, environmental and social, was formally reported on annually ${ }^{28}$ (CA 1999, CRC 2008). At the same time, community development workers, often employed by Rural Community Councils ${ }^{29}$ (Bracey 1959 pp125-129) increasingly encouraged, as they still do (ACRE 2012), local people to use community planning tools (DCA 2012, Planning for Real 2011, Rocktime 2011). It was also during this period that national politicians of all parties began to talk more about how power might be devolved to local areas, with, from 1997, “... community leadership ... placed at the heart of local government reform.” (Sullivan 2007, p.1).

Throughout this period, however, responsibility for major policy areas was increasingly centralized (Morris and Nichols 2007, p.30), and local government powers and structures were altered. For example, the Local Government Acts of 1972 and 1974 dissolved rural district councils, many of which were centred on, and based in, country towns, and created fewer, larger, less local borough/district councils (Cloke 1983, p.201). In the mid-1990s, some - relatively few - shire county and borough/district councils merged, "... as part of [of a] local government reorganisation ... designed to introduce an entirely unitary pattern of local government across Britain ..." (Stevens 2006, p.75). Neither this reorganization, nor a subsequent attempt in the mid-2000s, were completed. Therefore, although the intention was to simplify local government structures, and reduce the number of authorities, the result was an increase in the number of structural types, with no significant reduction in number.

None of the changes to local authorities described above have materially affected the smallest, but most numerous, tier of local government - town and parish councils. Their powers remain substantially unchanged. They have few responsibilities but relative freedom to provide local services and facilities, such as the provision of allotments (i.e. land rented by individuals, typically for growing vegetables), clocks, and community centres (Stevens 2006, p.73). Although the powers available to town councils are the same as those of the smallest - village - parish council, towns, being generally larger, can more easily raise money and employ staff.

Overall, however, the trend is towards "bigger", more centralized government. For example, the present UK government's policy relating to academies (DfE 2012) effectively removes school management and control from local authorities, and places ultimate power in the hands of central government's Department for Education (DfE 2012a). Therefore, confusingly, although both

\footnotetext{
${ }^{28}$ The Countryside Agency produced annual 'State of the Countryside' reports between 1999 and 2004. From 2005 until 2008, the reports were published by the Commission for Rural Communities, the Countryside Agency’s successor (see http://tinyurl.com/bsmajkg).

${ }^{29}$ Rural Community Councils (RCCs) are voluntary organizations based in the rural - shire - counties (NB shire is the traditional term for many English rural counties, e.g. Northamptonshire). RCCs provide advice about such things as village halls (community buildings), rural services, and grant availability. They also work in partnership with other organizations. Essentially their aim is to help the people of rural England.
} 
Conservative and Labour governments have increasingly expected, “ ... local government ... to dance to central government's tune.” (Stevens 2006, p.167), political rhetoric has simultaneously stressed the need to devolve powers; to decentralize.

This wish to devolve powers, whilst being reluctant to re-empower local democratic government, helps to explain why partnership working, in which local authority representatives are often minority members, rather than leaders (DETR/MAFF 2000, p.78), is the norm in programmes sponsored by central government. The origins of this lie partly in the post-war central-local government settlement. As part of the creation of the welfare state in which local authorities were to play a major role, this produced a, “... marked willingness on the part of local councillors to accept a degree of central direction in policy development.” Unsurprisingly, this led to, “... a growing tendency for the central government to regard all local activities of financial significance as a matter for central concern." (Young and Rao 1997, p.117).

The move towards today's model of partnership working has its roots in the 1970s, when the so-called New Public Management, designed to contain public spending using private sector techniques, was introduced (Bevir and Rhodes 2003, pp.71-72). It accelerated with the growth of programmes such as the Single Regeneration Budget, and Urban and Rural Challenge schemes (Jones and Little 2000) in the 1990s, and Community Strategies and Local Strategic Partnerships in the 2000s (CA 2004). The recently established Local Enterprise Partnerships are essentially a continuation of this way of working (DBIS 2012).

Arguments and debates about partnerships have been well-rehearsed. They centre on the shift from government to governance, and continuing political debates about the most appropriate scale, scope and structure of organizations and their responsibilities, be it at the regional or city-region level, for best effect (Bentley et al 2012, Ravetz 2000, SWRDA 2011). Of course, questions remain about democratic legitimacy, complexity, effectiveness, and sectoral/organizational/individual dominance of decision making and associated processes. Jones and Little (2000, p.182) note that partnership working as the norm for public sector programmes in rural areas was based on urban practice. Consequently, therefore, then Conservative Government's Rural Challenge programme in the 1990s (derived from, and analogous to, the Urban Challenge programme), did not allow for rural differences in terms of, “... power relations, accountability, public spending levels, and equitable resource allocation in ... addressing ... the needs of rural communities.” (p.182).

The emphasis on urban, rather than rural, renewal was also characteristic of the New Labour governments. Cities, in many ways the Labour party's heartland, were central to government policy (Parkinson and Boddy 2004 p1), with partnerships at the centre of policy implementation, even though the drawbacks outlined above were recognized, and caused concern (p.363). Although MTI 
partnerships were relatively small in terms of membership numbers, geographical reach, and their finances, ${ }^{30}$ these drawbacks were also noted by participants in the programme (Caffyn 2004, Morris 2008, 2010),

The reality, however, is that, by 2000, partnership working was deeply embedded in governmentsponsored programmes such as the MTI. This is evident from the description of the programme given in the next section, in which the research method is also described. Following this, and an overview of the research findings, some of the achievements of the partnerships are presented.

\section{The $\mathrm{MTI}$ - origins, aims and approach}

The MTI arose from two white papers specific to rural England (DoE /MAFF 1995, p.57, DETR/MAFF 2000, pp.74-78). Designed and supported by public sector organizations, it was designed to be led by groups of local people, many of whom were volunteers. In part its creation can be attributed to the many people who, during the mid-1990s, throughout rural England, began to express, simultaneously and unprompted, concern about the state of their small towns. Much of the concern then (DETR 1998), as now (Portas 2011), was about the growth of supermarkets and out-oftown shopping centres built away from traditional small town shopping and employment centres.

Consequently, the MTI was primarily regarded as a "tool” to, “... help create new job opportunities, new workspace, restored high streets, improved amenities and transport facilities and help with community needs.” (DETR/MAFF 2000, p.75). A total of GBP £32 million was allocated, over three years, to England's regional development agencies (RDAs), and GBP $£ 5$ million to the Countryside Agency. In essence the job of the former, economic-development orientated, agencies was to advise on and help pay for a variety of projects in the towns, provided the projects met the agencies' criteria for support.

The Countryside Agency's initial job was to design and develop a stock-taking and project planning process called the Healthcheck (DETR/MAFF 2000, p.75). This was used to help local people assess their town's strengths and weaknesses in relation to the environment, transport, accessibility, and wider social and community concerns, as well as the RDAs' primary concern, the economy. The Countryside Agency also contributed to the cost of employing coordinators to help locals conduct Healthchecks, and project managers to help develop and implement projects arising from the Healthchecks.

\footnotetext{
30 The total MTI budget from central government was $£ 37 \mathrm{~m}$. This compares with more than $£ 2$ bn allocated to the New Deal for Communities programme (ODPM 2000 p112).
} 
The end of the programme in 2005/6 coincided with the closure of the Countryside Agency. The regional development agencies continued to support the partnerships in their regions, but the work gradually ceased, and the agencies themselves had closed by the end of April 2012.

The limitations of public sector "short-termism" are well known (Blackburn et al 2003, p.45, DCLG 2006, p.55). So too is the complicated nature of local governance (Hewitt 2011, Morris and Nichols 2007, pp.10-17, Morris 2008, p.3). It is not surprising, therefore, that the MTI's success, and its potential to inform future work, was limited by its short life relative to the time needed to embed community-led development into the complex network of local government and governance structures. Nevertheless, the programme lasted longer than the three years for which it was initially budgeted, and many of the partnerships continue their work (Carterton Town Council 2012).

Estimates as to the number of towns that eventually took part in the programme vary between 227 and 240 (Morris 2010, p.21). The former figure is the official total (Hansard 2007). The latter, based on information gathered informally towards the end of the programme, is anecdotal. Irrespective of the actual total, the initial target of 100 participating towns (DETR/MAFF 2000, p.75) was exceeded. This, coupled with the programme's extended life, and participants' broadly positive views, indicates, as discussed below, that, whilst limited in terms of achievements, local control and evaluation, ${ }^{31}$ the approach was successful, and worthy of development. First the research method is described.

\section{Investigating the MTI}

\section{The research method}

All the information in this and subsequent sections is, unless stated otherwise, taken from the writer's thesis (Morris 2010). In essence the research was an attempt to "tell the story" of the MTI through the eyes of local participants; there being little else in the way of systematic evaluation on which to draw.

Information was gathered via a postal questionnaire and semi-structured face-to-face interviews. Although most of the participants came from the towns (e.g. chairs of partnerships, town clerks), some were drawn from surrounding, often traditional hinterland, areas. Officials and others involved in rural development and related policy and practice also took part. The questionnaire and interview guide were finalised following a series of trial interviews with a variety of people (professional, political, and lay) involved in community development in the UK, and, in one case, overseas. Interviewees included the chief executives of the Countryside Agency and a rural regeneration charity, an official from a regional assembly, ad local authority officers and councillors.

\footnotetext{
31 My research effectively became part of an informal, uncoordinated and rather stuttering evaluation of the MTI work, aspects of which were investigated during the period when the programme was operational (ERM 2001, Entec 2004, Moseley, Owen, Clark, and Kambites 2005). Earlier work assessed town characteristics and vulnerability (ERM 2001). The MTI was never methodically evaluated nationally.
} 
Twelve questions were asked. Mainly descriptive, they explored reasons for involvement, expectations, partnership achievements and current operational status. Although the questioning was designed with qualitative answers in mind, some respondents and interviewees offered quantitative information suitable for analysis.

In order to corroborate the information obtained from the primary sources of data (i.e. the questionnaires and interview transcripts), some Healthchecks and associated Action Plans were analysed and used as comparative sources of information about the type of work done by partnerships.

Eventually, questionnaires and explanatory letters were sent to 48 towns, approximately $20 \%$ of the 227 towns that officially participated. Initially every sixth town on the official list was selected in order to ensure a degree of randomness. Following this, additional towns were selected to ensure that at least one town from each of the eight English rural regions was included.

In addition, the 18 Beacon Towns were included (DETR/MAFF 2000, p.75). These were selected, mainly by regionally-held competitions, both for the long-term (10-year) potential of their partnerships' topic work to help others, and to inform policy (Nichols 2004, 2005). Their inclusion ensured that any points arising from their work on, for example, enterprise support, integrated service provision, renewable energy, migrant workers, local food, housing, and transport, would be captured. Also included, for purposes of comparison and learning, was one town in which a Healthcheck was conducted in conjunction with the Sustainable Livelihoods approach used overseas by the UK government’s Department for International Development (Butcher et al 2003).

Two other programmes, One Stop Shops (CA 2003) and Gateway Stations (Nichols 2004a, 2005a), were incorporated into MTI work. The former was designed to encourage the creation of multi-use centres (the "shops") in which a variety of services could be combined cost-effectively; e.g. an information centre combined with training, meeting, and computing facilities in Haltwhistle, Northumberland (Nichols 2005, p.60). The latter was aimed at partnerships wanting to improve aspects of public transport associated with their railway stations (e.g. the employment of a Railway Development Officer to raise awareness and increase usage of Sandown station, Isle of Wight). Where possible, other less-closely related programmes such as the Local Heritage Initiative ${ }^{32}$ and Vital Villages, were also linked to MTI work.

Eventually, 30 completed questionnaires were received from 27 towns (in three towns, two people answered the questions). In all, 49 people contributed to the research. This number includes exploratory interviews with four people involved in the MTI in two towns, trial interviews with five people, and face-to-face interviews with 10 people involved with the MTI partnership in Bridport,

\footnotetext{
${ }^{32}$ http://tinyurl.com/dy3tkyr
} 
Dorset. The respondents and interviewees were representative of those involved in the work. They included local volunteers, town clerks, and councillors from all tiers of local government, officials from local authorities, and a regional development agency, and a regional government office. In all 28 partnerships contributed to the research, a participation rate of about $58 \%$.

When transcribed, the data amounted to more than 37,000 words of fact and opinion. The information was wide ranging and informative, but, given the relatively small sample size, limited. Therefore, rather than attempt to establish causal links between, e.g. the extent to which a partnership's success was dependent upon factors such as demography, previous involvement in public sector programmes, a town's location in a development area, or particularly supportive local organizations, all of which are worth exploring, the participants' anonymized contributions were analyzed to allow their - mainly local stories and messages to flow. With the data reduced to a manageable and intelligible form, it was relatively easy to organize and present the findings. These are discussed in the next section.

\section{Research findings were broadly positive, but ...}

Essentially the research revealed the encouraging, though not surprising, finding that people care about the places they live in. They are prepared to work hard (for nothing) to improve their towns. They have skills, and specific, as well as general and often professional, knowledge and experience. Their views varied from the very positive to the less than enthusiastic. There is evidence that local loyalties, local knowledge, an awareness of local needs, belief in the ability of locals to identify and, given the chance, to solve problems, and capitalize on group and individual strengths, draw people together for common purpose and the common good.

Overall, the opinions given and experiences described were similar, with one significant exception. In the South West, where the MTI operated concurrently with the RDA-led region-specific Market and Coastal Towns Initiative (RTP 2002), the presence of two similar and not always well-integrated programmes caused some confusion. This was particularly marked in the case of Bridport, which had the added status (or burden, depending on the point of view) of being the South West's only Beacon Town. More generally, terminology and jargon caused confusion, frustration and disappointment at times, as did over-blown, although well-intentioned, promises, especially about the availability of, and ease of getting, money.

The distribution of the programme's overall budget between the Countryside Agency and the eight RDAs meant that, rightly, each organization had its own programme of work. The extent to which the Countryside Agency's national monitoring role via the England Market Towns Advisory Forum, and its local support and enabling responsibilities (i.e. the Healthcheck and contribution to the employment of coordinators and project managers) were successfully integrated with the RDAs' work, varied. In the writer's view, successful integration was achieved largely as a result of good personal working 
relationships between the staff of the various organizations, a willingness to appreciate the different priorities of each organization, and the associated pressures acting on all involved. Matters were not helped by the fact that the finite life of the MTI meant that the data gathering and project identification/planning work (i.e. the Healthcheck, action planning) and the RDAs' budgetary need to spend MTI money on projects within the same timescale, often had to coincide (i.e. the two elements of the work were time constrained to be concurrent, rather than, as they should have been, logically, sequential).

However, a clear majority of participants thought that the programmes of work were broadly successful, although by no means perfect. When asked to rate their hopes, achievements and satisfaction with the programmes, rather than their projects, the majority of views were positive (Morris 2010, p.157). Overall, the 41 projects given as examples of the work done, and illustrated in Table 1 , reflect this generally positive view.

Table 1: Examples of fully or partially implemented projects

Examples of fully or partially implemented projects, provided by interviewees and respondents (Morris 2010 Table 14)

1. Programmes of events

2. Small projects fund

3. IT projects

4. Business Support Fund

5. Skills training

6. Sports centre feasibility study

7. Community Resource centre

8. Fire station redevelopment

9. Astro turf and sports facilities

10. Canal towpath and mooring improvements

11. Canal boat project

12. Car parking

13. Traffic-related projects

14. Housing projects

15. Improved Car Parking

16. Two Youth Café projects

17. Traffic management

18. Public Realm Improvements

19. Restoration of mainline railway station platforms

20. Directory of sports clubs

21. Credit Union

22. Improved police support

23. Affordable and diverse Housing

24. New Outdoor Youth Facility

25. Coastal Strip Evaluation

26. Creation of Heritage Rail trips

27. Additional Business Space

28. Service provision

29. Achievement of Quality Town Council status

30. Shrub and tree planting

31. Local radio projects

32. Local festivals (e.g. arts \& youth)

33. Various village hall improvement projects

34. Completion of urban design framework leading to leisure and retail developments

35. Sixteen bungalows for elderly, and twenty rented and shared equity homes built and occupied

36. Day centre

37. Website

38. Door to door car service

39. Cultural arts programme

40. Improvements to riverside

41. New neighbourhood groups

\section{... participants' experiences were not wholly positive}

It is not surprising that participants' opinions and experiences were not entirely positive. Although it is probable that those with positive stories are most likely to tell them, those with particularly poor experiences are also likely to relate their tales. It is also probable, and particularly frustrating for the researcher, that, for reasons to do with, e.g., a lack of time, or faith in the MTI, those whose experiences fall between enthusiasm/success and exasperation/failure (i.e. the disengaged, the sceptical/cynical, the uninterested, and the conscripted), are the least likely to participate. 
The views and experiences reported by the postal survey respondents were matched by the fuller information provided by the interviewees. The point was made by a community development officer, that, "In general action planning has worked, but more emphasis should be given to supporting locals to help themselves." The need for support can be inferred from the comments of other interviewees, one of whom, a volunteer, remarked, "We should have gone for a major project head-on, first off, rather than each little group asking for something - too many minimal projects.”, while an official stated bluntly, “... I expected it to fail miserably after four years, and that's what it's done.” Despite these views, a majority of participants reported that progress had been made in implementing plans, indicated that the work had met their expectations (Morris 2010, p.157), and stated that the majority of partnerships (67\%) were still active in 2008 (p.175).

In addition, various factors governing the success of community-led development were identified by the participants in the research. These are illustrated in Table 2.

Table 2: Community-led development: What's needed for success?

A Summary of points from the research relating to people, time, and structures (Morris 2010, Table 18 p.182) People...

- $\quad$ Knowledgeable, individual, unpredictable, loyal, and opinionated, they are crucial, central, need to be nurtured and involved, and trusted with the truth about programme limitations.

- $\quad$ Need clarity about programme aims, limitations, and governing processes.

- $\quad$ Need clarity about local needs and agreed aims, for when a clearly-defined and obvious need exists, and is understood and accepted, support and consequent success can quickly follow.

- $\quad$ Need mechanisms that enable effective and open communication - based on trust.

- $\quad$ Need support and training (not easy/possible with programmes that last only a few years).

- $\quad$ Need to have realistic aims and expectations.

- In the main have a natural affinity with, and loyalty to their town/area, and a desire to contribute.

- $\quad$ Need structures and processes that recognize that they tire, come and go for all sorts of reasons, and will one day need to be replaced (succession strategies).

- $\quad$ Disagree at times, and so need ways that encourage constructive debate and enable conflicts to be resolved.

\begin{tabular}{l}
\hline Pressure to start work and achieve quickly does not \\
\hline - $\quad$ Time \\
- $\quad$ meet sponsoring organizations' aims in terms of success and value for money. \\
Short-term programmes do not suit long-term community development needs in terms of success and value for \\
money. \\
Recruiting, supporting, and ultimately replacing people to do work that is often volunteer led takes time - in many \\
ways the work never ends. \\
- $\quad$ Partnerships need to be simple, stable and organized in such a way that they have defined delegated powers and \\
the wherewithal to get things done, but ... \\
-.. also need to reflect the fact that members (often volunteers) will tire, will change, and often have other \\
responsibilities. \\
Need to be stable, capable of providing long term, consistent commitment to the development, monitoring and \\
evaluation of programmes and approaches, together with a need to recognize that success cannot be guaranteed, \\
for failure is always - an uncomfortable - possibility. \\
Need to be inclusive (the importance of the role of town and other councils in enabling and supporting community- \\
led work should not be underestimated).
\end{tabular}


The points made by participants (Table 2) suggest an overall lack of time, not only to allow people to prepare for the work, but also to gather sufficient evidence to support partnerships' plans and project bids. For example, the need for evidence was reinforced by an RDA officer, who noted that, in one town, “... a lot of the evidence base ... wasn't apparent ...”, before adding that plans in other towns contained ... a whole bulk of evidence to back up the plan ... ." This illustrates not only - the inevitable - differences in the quality of Healthchecks, but also hints at some of the reasons for such differences.

These differences include the availability of information, the ability (e.g. in terms of time, money, knowledge) of local people to find, collate and present information, previous local experience of, and benefit from, publically funded and administered regeneration programmes, and the amount of support available to partnerships from, e.g. local authorities and voluntary organizations. The fact that the programme was - unusually - available throughout rural England, and had a common methodological and funding format, means that evidence about the impact of these variables on the effectiveness of partnerships and their ways of working could have been gathered relatively easily. Although not comprehensive, sufficient information was obtained to enable some of the conditions necessary to minimize the likelihood of partnership failure to be identified. These are presented in Table 3. One conclusion that can be drawn from these data is that more information about ways of working and likely success and failure factors could have been obtained from a formal evaluation of the MTI. This, and other conclusions, are discussed in the next section.

Table 3: Conditions necessary to help minimize failure

Conditions necessary to help minimize partnerships' likelihood of failure(Morris 2010, Table 23 p.221)

- Sufficient time to form and organize partnerships, and to create and maintain relationships between members.

- $\quad$ Political and wider community support for the members of partnerships (i.e. greater awareness and support from local populations, with implications for the representativeness of partnership members, and need for democratic accountability recognized).

- $\quad$ Straightforward long-term processes and programmes that are designed to allow and encourage their evolution/development, and information/experience sharing.

- $\quad$ Partnerships with sufficient power and authority to develop and implement plans.

- $\quad$ Partnership members sufficiently well trained and supported to assume the necessary responsibilities.

- $\quad$ Effective communication between partnership members and associated organizations.

- Organizational and individual patience to enable the plans to be brought to fruition.

- Structures that take into account people's limited time and energy, and the associated requirements for personal/organizational development and succession strategies.

\section{Conclusions}

The MTI worked. The programme's structure did not, as Julia MacLeavy (2009, p.871) noted in connection with her analysis of partnership work in Bristol, “... constitute genuine empowerment.”, but the aims and targets set for it were exceeded, in that far more than 100 towns participated, 18 Beacon Towns were selected (the initial aim was between 10 and 20), related programmes such as Gateway Stations and One Stop Shops were integrated into the programme, and the majority view of 
the participants was positive. However, if the programme guidance had included a requirement to evaluate as well as monitor the work done by the partnerships, then the experiences of the volunteers, paid professionals and other advisers involved could have been used to improve it, and to inform the development of subsequent, or continuation, programmes. Nevertheless, the concerns identified and the subjects discussed by those involved (Table 4) provide plenty of pointers towards future needs and work.

Table 4: Concerns identified by MTI Partnerships

Concerns Identified and Subjects Discussed by Market Towns Initiative Partnerships (Morris 2010, p.114)

\begin{tabular}{|c|c|c|}
\hline $\begin{array}{l}\text { Main Concerns Identified in MTI } \\
\text { Partnerships' Healthcheck } \\
\text { (Moseley, et al } 2005 \text { p38) }\end{array}$ & \multicolumn{2}{|c|}{$\begin{array}{l}\text { Main Subjects Discussed by MTI Partnerships (from } 317 \text { interviews } \\
\text { with officers \& members: views in order of importance) } \\
\text { (Entec } 2004 \text { p16 [after Chart 2.2]) }\end{array}$} \\
\hline Officers & \multicolumn{2}{|c|}{ Members } \\
\hline $\begin{array}{l}\text { - } \quad \text { Road traffic } \\
\text { Deficiencies of the town } \\
\text { environment } \\
\text { - } \quad \text { Inadequacies of public transport } \\
\text { - Inadequacies of facilities for young } \\
\text { people } \\
\text { Inadequacies of leisure and } \\
\text { recreation facilities } \\
\text { - } \quad \text { Poor range and quality of local } \\
\text { - } \quad \text { Neglect of towns' tourism potential } \\
\text { - } \quad \text { Insufficient facilities and support } \\
\text { - } \quad \text { Poor local business } \\
\text { - } \quad \text { Affordable housing } \\
\text { - } \quad \text { Health and health-care issues } \\
\text { NB } \quad \\
\text { The principal concern in larger towns } \\
\text { was road traffic, whereas in smaller } \\
\text { towns local services caused most } \\
\text { concern. When the results of research } \\
\text { into } 40 \text { Healthchecks were compared } \\
\text { with earlier research into } 24 \\
\text { Healthchecks (Shorten and Bell 2002) a, } \\
\text { “... remarkable degree of common } \\
\text { ground was apparent." (Moseley et al. } \\
\text { 2005 p38). }\end{array}$ & $\begin{array}{ll}\text { - } & \text { Project delivery, progress } \\
\text { - } & \text { \& Action Plan } \\
\text { - } & \text { Partnershing } \\
& \text { and future role } \\
\text { - } & \text { Transport } \\
\text { - } & \text { Economic } \\
\text { - } & \text { Social } \\
\text { - } & \text { Bureaucracy } \\
\text { - } & \text { Local Authority role } \\
\text { - } & \text { Environmental } \\
\text { - } & \text { Regeneration } \\
\text { - } & \text { Speed of delivery } \\
\text { - } & \text { County Council's \& } \\
& \text { RDA's role } \\
\text { - } & \text { Internal process issues } \\
\text { - } & \text { Other - see below }\end{array}$ & $\begin{array}{ll}\text { - } & \text { Project delivery, progress \& } \\
\text { - } & \text { Action Plan } \\
\text { - } & \text { Environg } \\
\text { - } & \text { Economic } \\
\text { - } & \text { Internal process issues } \\
\text { - } & \text { Social } \\
\text { - } & \text { Regeneration } \\
\text { - } & \text { Transport } \\
\text { - } & \text { Partnership's constitution and } \\
\text { - } & \text { future role } \\
\text { - } & \text { Speed of delivery } \\
\text { - } & \text { Bureaucracy } \\
\text { - } & \text { County Council's/RDA's role } \\
\text { - } & \text { Other - see below }\end{array}$ \\
\hline \multicolumn{3}{|c|}{ Topics discussed under "Other" headings above } \\
\hline $\begin{array}{ll} & \text { Affordable housing } \\
\text { - } & \text { Long-term strategies and planning/r } \\
\text { - } & \text { Market Town programme } \\
\text { - } & \text { The role/involvement of particular m } \\
\text { - } & \text { Youth issues } \\
\text { - } & \text { Crime and policing } \\
\text { - } & \text { Public reaction } \\
& \text { Good practice }\end{array}$ & $\begin{array}{l}\text { aster planning } \\
\text { mbers/agencies }\end{array}$ & \\
\hline
\end{tabular}


Although work continues in many towns, the reality is that much is now essentially local and discrete, apart from exceptions such as the work done by the South East Rural Towns Partnership (SERTP 2012), Action for Market Towns' annual awards competition (AMT 2012) and town centre “benchmarking” work (AMT 2011), and related research (Powe and Bek 2012, STfT 2012). The idea of each partnership as a contributing member of a nationally coordinated and managed learning network designed to benefit both rural England and policy development has been lost. Equally concerning is that, as the organizations involved in the programmes have closed (Countryside Agency, regional development agencies ${ }^{33}$ ), or had their budgets cut (local authorities and rural community councils), experience and “institutional memory” have also been lost.

For the writer, the programme raised questions about the implications for local democracy of partnership working. Local people (the community) have long been involved voluntarily in local work and projects, and there are many examples of how such joint working has been encouraged (CA 2004a, Eden DC 2012, ODPM/Urbed 2002). The desirability of local people working for the common good is not in question, any more than is the willingness of many people to do so. However, the influence that the interested but unelected have on matters that could be said to be the responsibility of the elected, is, although beyond the scope of this paper, worthy of further research. For example, given current concerns about globalization, the power of lobby groups, and the paradox of central governments that appear both remote and controlling, now would be a good time to revisit the roles of local government with a view to dispersing significant powers and responsibilities in ways that go far beyond the limited ambitions of clichéd terms such as "localism", "double devolution", and the imprecision of the "Big Society".

It is worth pointing out the obvious: councillors are community leaders (Morris and Nichols 2007, pp.10-11), and are often, effectively, unpaid volunteers. Similarly, town councils, as stable statutorily constituted, publically accountable organizations, were well placed to play a leading role in the work. Not all did, but those that were involved added value and provided partnerships with a measure of local democratic legitimacy.

As previously discussed, this is not to suggest that partnership working - or local government control - is a panacea. According to Ravetz (2000, p.263), “While community participation is generally held to be a "good thing", it is cursed by fuzzy thinking. The "law of oligarchy" shows that in any group ... an inner elite will emerge to manipulate the majority." It follows that future programmes should build on the work of Healthcheck coordinators, and project managers (many of whom were essentially community development workers), and partnership members, to ensure both that the views and needs

\footnotetext{
${ }^{33}$ That these organizations existed for barely longer than the MTI is indicative of the rate at which the machinery of government changes. Whatever the political imperatives behind such changes, it is indisputable that the inevitable disruption to people, programmes, and policy development and implementation, has costs that go beyond the purely financial.
} 
of the "voiceless" (e.g. the single parent, the unemployed, the frail, the poor) are heard and communicated to any "inner elites". It will also be necessary to ensure that sufficient skills are developed within towns to ensure that work can continue, when, as is likely, professional development workers leave to work elsewhere.

Given the hard work and achievements of all those involved in the programmes, there must be doubts about whether maximum value for money for the public purse was obtained. Although the MTI was broadly successful, an opportunity to learn was wasted. There was a failure to capitalize on the work. Little has changed, it seems, to challenge the view of Lord Scott's committee's seminal review in the 1940s, that, “... our great failures, both in war and peace, have been due to a failure to think ahead and make plans in advance." (HMSO 1942, p.89).

The MTI’s lessons for today's policy and programme makers are simple to understand, and important. Future policies must be designed to ensure that formal monitoring and evaluation is an integral part of programme implementation. This does not have to be onerous, as was demonstrated by the approach taken with the MTI-related Beacon Towns Programme. Based on relatively infrequent, informal visits during which the experiences, concerns and successes of participants were recorded and published, the process was simple to manage and relatively undemanding of partnership members and their time (Nichols 2004a 2005).

Finally, the research suggested that local democratic legitimacy and oversight of programmes such as the MTI remain important, and should not be subordinated to central government's desire to control from afar.

\section{Acknowledgements}

Wendy Cutts, Bournemouth University, UK, Ian Gray, Charles Sturt University, Australia, and Martyn Warren, of both the University of Exeter's Centre for Rural Policy Research, UK, and Plymouth University, UK, were kind enough to comment on aspects of this paper. Their help is gratefully acknowledged. The opinions expressed are those of the author alone. 


\section{References}

ACRE (2012) The Rural Communities Action Network. Action with Communities in Rural England, Cirencester, Gloucestershire, accessed at: http://tinyurl.com/co83vvd [June 2012]

AMT (2005) Market Towns Healthcheck Handbook. Action for Market Towns, Bury St Edmunds, Suffolk, UK. pp68, accessed at: http://tinyurl.com/boxfc2p [September 2012]

AMT (2011) Market Town Benchmarking - measuring the performance of town centres. 2010 National Report. Action for Market Towns, Bury St Edmunds, Suffolk, UK, accessed at: http://tinyurl.com/d8dbykn [11 September 2012]

AMT (2012) The 2012 National Action for Market Towns Awards. Action for Market Towns, Bury St Edmunds, Suffolk, UK, accessed at: http://tinyurl.com/6m5busm [February 2012]

Bentley G., Bailey D., and Shutt, J. (2012) rom RDAs to LEPs: A New Localism? Case Exampoles of West Midlands and Yorkshire. Forthcoming in Local Economy. pp24. The University of Birmingham, UK, accessed at: http://tinyurl.com/cgrvbee [ November 2012]

Bevir, M and Rhodes, R.A.W. (2003) Interpreting British Governance. ISBN 0-415-30452-0. Routledge, London

Blackburn S., Skerratt S., Warren M and Errington A. (2003) Rural Communities and the Voluntary Sector, a Review of Literature. Final Report. University of Plymouth, Seale Hayne, Newton Abbot, Devon, UK. pp83

Bracey H.E. (1952) Social Provision in Rural Wiltshire. London: Methuen \& Co. Ltd.

Bracey H.E. (1954) Towns and Rural Service Centres: an Index of Centrality with Special Reference to Somerset. The Institute of British Geographer, Transactions and Papers, 1953, 19, 95-10

Bracey H.E (1959) English Rural Life. Routledge and Kegan Paul Ltd., London

Bracey H.E.(1962) English central villages: identification, distribution and function. Land Studies in Geography, Series B, Human Geography. 24, 169-190

Bracey H.E. (1963) Industry and Countryside - the Impact of Industry on Amenities in the Countryside. Acton Society Trust, Faber and Faber Ltd., London.

Bramley G. and Smart G. (1995) Rural Incomes and Housing Affordability. ISBN 186996445 4. Rural Development Commission, Salisbury, UK. pp106

Butcher C., McDonald B. and Westhorp, V. (2003) Healthchecks and Sustainable Livelihoods: a case Study From Kent. In: Community Development Journal, 38, 3, 225-234

CA (1999). The State of the Countryside 1999. ISBN 086170638 2. The Countryside Agency, Cheltenham, UK

CA. (1999a) Tomorrow's Countryside - 2020 vision. The Countryside Agency, Cheltenham, UK

CA (2000) Market Towns Toolkit. The Countryside Agency, Cheltenham, Gloucestershire, UK

CA (2003) Setting up One Stop Shops - a good practice handbook on linking services in market towns. The Countryside Agency, Cheltenham, UK.

CA (2004) Planning for Vital Communities. The Countryside Agency, Cheltenham, UK. pp20.

CA (2004a) Assessment of the Market Towns Initiative: a Summary. The Countryside Agency, Cheltenham, UK. pp24

Caffyn A. (2004) Market Towns Regeneration; Challenges for Policy and Implementation. Local Economy 19(1), pp8-24

Cameron D. (2011) Leadership for a better Britain, accessed at: http://tinyurl.com/d6nndgg [07 June 2012]

Carterton Town Council. (2012) Carterton fast-forward partnership, accessed at: http://tinyurl.com/ck7o4xb [07 June 2012]

Chalkin C.W. (1989) Country Towns. In: Mingay, G.E., The Rural Idyll. Routledge, London. Chapter 3

Chamberlin R. (1984) The English Country Town. Webb \& Bower (Publishers) Ltd., London

Cloke P. (1983) An Introduction to Rural Settlement Planning. ISBN 0-416-73800-1. Methuen, London 
Cloke P., Milbourne P. and Thomas C. (1994) Deprivation, Poverty and Marginalization. In: Rural Lifestyles in England and Wales. Journal of Rural Studies 11, (4), 351-365

Conservative Party (2009) Strong Foundations. Building Hopes and Communities. Policy Green Paper Number 10. The Conservative Party, London. pp40

Courtney P,, Dawson J. and Errington A. (1998) The Functions of the English Market Town: a Comparison Between Devon and Cornwall. University of Plymouth (Seale Hayne), Newton Abbot, Devon, UK

CRC (2007) The State of the Countryside 2007. Commission for Rural Communities, Cheltenham, UK

CRC (2008) The State of the Countryside 2008. Commission for Rural Communities, Cheltenham, UK

DBIS (2012) Local Enterprise Partnerships. Department for Business Innovation and Skills, London, accessed at: http://tinyurl.com/5vs3bqm [26 November 2012]

DCA (2012) Parish and Neighbourhood Plans. Dorset Community Action - Support for Communities, accessed at: http://tinyurl.com/d38xt3m [05 June 2012]

DCLG (2006) Strong and Prosperous Communities - The Local Government White Paper (CM 6939-I \& II) Summary. Department for Communities and Local Government, London. pp8

DCLG (2011).A Plain English Guide to the Localism Act. Department for Communities and Local Government, London. pp19

Defra (2012) Statistical Digest of Rural England. Defra Publications, Smith Square, London, accessed at: http://tinyurl.com/7wovsme [30 June 2012]

DETR (1998) The Impact of Large Foodstores on Market Towns and District Centres. ISBN 0117534781. The Stationery Office, Norwich, UK

DETR/MAFF (2000) Our Countryside: The Future. A fair deal for rural England (Cm 4909). The Stationery Office, Norwich, UK. pp74-100

DfE (2012) Michael Gove Speech on Academies. Department for Education, London, accessed at: http://tinyurl.com/cu2kk5l [06 June 2012]

DfE (2012a) Academy Governance. Department for Education, London, accessed at: http://tinyurl.com/8m4s7qq [07 September 2012]

Diocese of Hereford. (1987) The People, The Church and The Land. ISBN 090287308 3. The Hereford Diocesan Board of Finance, The Palace, Hereford. pp211

DoE/MAFF (1995) Rural England, a Nation Committed to a Living Countryside (Cm 3016). Her Majesty’s Stationery Office, Norwich, UK

Eden DC (2012) Eden Valley Communities - Big Society in Action. Eden District Council, accessed at: http://tinyurl.com/7d5366k [22 February 2012]

Entec (2004) Countryside Agency - Assessment of the Market Towns Initiative. Entec UK Ltd., Shrewsbury, Salop. UK

ERM (2001) Indicators for Assessing the Character and Vulnerability of Market Towns in North West England. Environmental Resources Management, London. pp5-7

Geddes M. (2000) Tackling Social Exclusion in the European Union? The Limits to the New Orthodoxy of Local Partnership. International Journal of Urban and and Regional Researh. 24.4. December 2000. pp782-800

Green F.H.W. (1949) Motor-bus Centres in southwest England, considered in relation to population and shopping facilities. The Institute of British Geographers, Transactions and Papers, 1948, 14, 57-68

Green F.H.W. (1952) Bus Services an Index to Changing Urban Hinterlands With Particular Reference to Somerset. The Towns Planning Review, January, pp245-356

Greene M. R. (2007) Electric Lyme. The coming of electricity to an English seaside town. ISBN 100 9552675-0-1. Martin Roundell Greene, Crewkerne, Somerset, UK. pp181

Griffith J. A. G. (1985) Foreword. In: Loughlin, M., Gelfand, M. D., and Young, K. Half a Century of Municipal Decline, 1935-1985. George Allen \& Unwin, London 
Hansard (2007) Market Towns Initiative, Question by Andrew George, MP, to Alun Michael, MP, Minister of State. United Kingdom Parliament, London, accessed at: http://tinyurl.com/7ay7ew5 [08 February 2012]

Hetherington P. (2012) Public health will cost local government. In: The Guardian. 27 June 2012, accessed at: http://tinyurl.com/7ayrlsx [27 June 2012]

Hewitt S. (2011) The impact of regionalisation on rural development in England. Paper given to the Regional Studies Association's International Conference, April 2011. University of Newcastle, UK. pp27

HMSO (1942) Report of the Committee on Land Utilisation in Rural Areas (Cmd. 6378). His Majesty’s Stationery Office, London. pp138

Jones O.and Little J. (2000) Rural Challenge(s): Partnership and New Rural Governance. Journal of Rural Studies, 16 (2000) 171-183

MacLeavy J. (2009) Re)Analysing Community Empowerment: Rationalities and Technologies of Government in Bristol's New Deal for Communities. Urban Studies, 46, 849-875

Miliband D. (2006) Putting People in Control. Speech to NCVO

Mills E. (1980) Changes in the Rural Spatial Economy of an English County (Somerset), 1950-1980. Thesis, University of Bristol, Bristol, UK

Minton A. (2012) Ground Control. ISBN 978-0-241-96090-5. Penguin Books, London

Morris G.R. (2003) 2002, a Spatial Odyssey. An Investigation Into the Sphere(s) of Influence of Sherborne, Dorset (an English Country Town). The University of Plymouth (Seale Hayne Campus), Plymouth, UK, accessed at: http://tinyurl.com/o4el7q [15 November 2011]

Morris G.R. (2008) IThe Impact of Organizational, Policy and Porgramme Changes on the Effectiveness of Market Town Partnerships. Rural Futures Conference, University of Plymouth, UK, accessed at: http://hdl.handle.net/10036/23933 [22 November 2012]

Morris G.R. (2010) People Helping People. An assessment of the Market Towns Initiative and Related Initiatives, and the Extent to Which They Addressed Rural Poverty. University of Exeter, accessed at: http://hdl.handle.net/10036/3076 [09 November 2011]

Morris G and Nichols C. (2007) Strengthening the Role of Local Councillors: an overview of information, policy and debate. Commission for Rural Communities, Cheltenham, Gloucestershire, accessed at: http://tinyurl.com/43krtlr [09 November 2011]

Moseley M.A. and Clark M. (1998) An Evaluation of the Impact of Dorset Rural Development Programme, 1994-1998. Countryside \& Community Research Unit, Cheltenham and Gloucester College of Higher Education (now the University of Gloucestershire), Cheltenham, Glos. GL50 4AZ. pp58

Moseley M. Owen S., Clark M., and Kambites, C. (2005) Local Issues in Rural England - messages From the Parish plans and Market Towns Healthcheck. Final Report to the Countryside Agency. Countryside and Community Research Unit, University of Gloucestershire, Cheltenham, UK

Nichols C. (2004) Beacon Towns: Signalling a Bright Future for Market Towns. The Countryside Agency, Cheltenham, UK

Nichols C. (2004a) A Partnership Story: Getting Things Moving. Report on the First Year of the Gateway Stations Programme. The Countryside Agency, Cheltenham, UK

Nichols C. (2005) Beacon Towns: The Story Continues. The Countryside Agency, Cheltenham, UK.

Nichols, C. (2005a) Gateway Stations: A Partnership Story - Final Report on the two-year Pilot Project. The Countryside Agency, Cheltenham, UK

Noble M. and Wright G. (2000) Identifying poverty in rural England. Policy and Politics. 28(3), pp.293-308.

ODPM (2000) Our Towns and Cities: the future. Delivering an urban renaissance. Office of the Deputy Prime Minister, London

ODPM/urbed (2002) Towns and Cities, Partnerships in Urban Renaissance, Volumes 1-4. Office of the Deputy Prime Minister, London

Pahl R.E. (1965) Urbs in Rure. The Metropolitan Fringe in Hertfordshire. Weidenfeld \& Nicolson, London.

Pahl R.E. (1970) Patterns of Urban Life. Longman Group Ltd., London 
Parkinson M and Boddy M. (eds) (2004) City Matters: Competitiveness, Cohesion and Urban Governance. The Policy Press, Bristol, UK

Powe N.A.and Bek (2012) Localising activity within the context of relational complexity: exploring the relevance of rural centre and town centre conceptions. Environment and Planning B: Planning and Design 2012, 39, (3), 501-517

Planning for Real. (2011) About Planning for Real ${ }^{\circledR}$, accessed at: http://www.planningforreal.org.uk/ [28 November 2011]

Portas M (2011) The Portas Review. An Independent Review Into the Future of our High Streets. Department for Business, Innovation and Skills, London. pp50

Ravetz J. (2000) City-Region 2020. Integrated Planning for a Sustainable Environment. ISBN 1853836060. Earthscan Publications Ltd., London. pp307

RDC (1996) Market Towns: a Commission Initiative. Paper for Commissioners, RDC CP(96)24. (held by the writer). Rural Development Commission, London

Rocktime (2011) What is a Parish Plan?, accessed at: http://tinyurl.com/bnjfcr5 [28 November 2011]

Rogers A. (1999) The Most Revolutionary Measure. A History of the Rural Development Commission, 19091099. ISBN 1869964 71 3, The Rural Development Commission, Salisbury, UK. pp142

RTP (2002) The SW Market and Coastal Towns Initiative Partnership. Evaluation of the Market and Coastal Towns Initiative (Pilot Phase). South West Regional Development Agency, Exeter, UK. pp40

Shepherd J. (2009) A Typology of the Smaller Rural Towns of England. Rural Evidence Research Centre, Birkbeck College, University of London, accessed at: http://tinyurl.com/868aorb [30 June 2012]

Shorten J. and Bell D. (2002) Summary of Analysis of Key issues Arising From Market Towns Healthchecks and Action Plans. University of the West of England, Bristol, UK, for the Countryside Agency, Cheltenham, UK

SERTP (2012) South East Rural Towns Partnership, Vibrant Towns, Vital Projects, accessed at: http://tinyurl.com/c8r2wua [14 March 2012]

Stacey M. (1960) Tradition and Change - a Study of Banbury. Oxford University Press, Oxford, UK

Stevens A. (2006) The Politico’s Guide to Local Government, Second Edition. ISBN-10: 1-84275-164-6. Poltico’s Publishing (Methuen), London

STfT (2012) Small towns of the future, not the past. Small Towns for Tomorrow, accessed at: www.smalltownsfortomorrow.org/wp.../07/STfT-Essay1-WEB.pdf [19 July 2012]

Sullivan H. (2007) Interpreting ‘Community Leadership’ in English Local Government. In: Policy and Politics, 35, (1), pp141-161

SWRDA (2000) South West RDA, A Short History. Bristol University, UK. pp46. Accessed at: http://tinyurl.com/cyw99cz [23 November 2012]

The Leeds Initiative (2009) Vision for Leeds 2011 to 2030. Development Plan and 'Where are we now?' Report. Leeds Initiative and Partnerships, accessed at: http://tinyurl.com/c69jrkw [22 November 2012]

UK Parliament (2011) Localism Bill 2010-2011, accessed at: http://tinyurl.com/365rous [23 January 2012]

Wheway C. (2012) The transformation of English market towns: gentrification. Leicester University, accessed at: http://hdl.handle.net/2381/10321 [07 September 2012]

Wilson D. (2012) Co-operation, not selfishness, is the key to human evolution. Co-operative News, accessed at: http://tinyurl.com/6uruqen [13 March 2012]

Woods M. (2005) Rural Geography. ISBN 0-7619-4761-2. Sage Publications: London

Young K. and Rao N. (1997) Local Government Since 1945. ISBN 0-631-19582-3. Blackwell Publishers Ltd., Oxford, UK 